\title{
Hungarian Ethnomusicologist Oszkár Dincsér (1911-1977) As a Pioneer of Musical Anthropology
}

\author{
Dániel LIPTÁK \\ Institute for Musicology \\ Research Center for the Humanities \\ of the Hungarian Academy of Sciences \\ Táncsics Mihály utca 7, Budapest H-1014, Hungary \\ E-mail: Liptak.Daniel@btk.mta.hu
}

(Received: November 2017; accepted: January 2018)

\begin{abstract}
There are marked differences between Hungarian and American ethnomusicology in incentives, aims, interests, and methods. Hungarian research was based in the early twentieth century on study of musical form, while the Americans approached music in terms of social context and functions. However, Hungarians from the mid1930s onward moved toward an increasing interest in the social aspects of folk music. Oszkár Dincsér, a lesser known researcher of Kodály's school, exemplifies this trend in his 1943 study of chordophone instruments in the Csík (in Romanian: Ciuc) County region of Transylvania Két csíki hangszer. Mozsika és gardon (Two instruments from Csík. Fiddle and gardon). A comparison with Alan P. Merriam's fundamental work The Anthropology of Music (1964) reveals that Dincsér's study includes almost every topic and approach set out by Merriam twenty years later. Although Dincsér's scholarly career ended with his emigration in 1944, he remains an important forerunner of musical anthropology.
\end{abstract}

Keywords: Oszkár Dincsér, Alan P. Merriam, musical anthropology, ethnomusicology

This paper sets out to reassess Zoltán Kodály's Hungarian school of ethnomusicology in an international context. ${ }^{1}$ Kodály was not simply one of the groundbreaking field workers, but the single most formative figure in Hungarian folk music research. He inspired generations of students at the Liszt Academy of Music and the University of Budapest, and he was also the initiator and first leader of an in-

1. I use the term "ethnomusicology" in a neutral, literal sense to mean any scholarly approach to folk music, including musicological, historical, and anthropological ones. 
stitutional framework for ethnomusicology. ${ }^{2}$ The focus here is on one of his pupils, Oszkár Dincsér, a lesser known scholar. In 1942, Dincsér conducted his last and most extensive fieldwork in the Hungarian-inhabited Csík (in Romanian: Ciuc) County which had been returned to Hungary from Romania under the $1940 \mathrm{Sec}-$ ond Vienna Award. Dincsér published his account of its instrumental culture in the following year. The paper argues that his book exemplifies a general tendency in inter-war Hungarian ethnomusicology toward an anthropological perspective.

Kodály's school of ethnomusicology has certainly been seen within Hungary as a great achievement. Yet there have been difficulties in communicating its findings abroad, due not only to unfavorable historical circumstances, but to inherent features in it that differ sharply from today's mainstream, at least at first sight. By way of the early work of Kodály and Bartók, the school clearly draws on nineteenth-century concepts of a politically and culturally autonomous country, and thus focuses on the Hungarian language area. It takes a primarily musicological shape, embodying a well-founded practice of formal analysis and a historical interest. Its underlying aim has been to systematize and publish the whole corpus of Hungarian folk music. Moreover, these aesthetic ideals and cultural aims are still with us.

However, much international research now derives from a new beginning made in the United States of America during the 1950-1960s, which can be called the school of musical anthropology. Taking a social rather than musicological view, its advocates would define ethnomusicology as "the study of why, and how, human beings are musical," ${ }^{3}$ so marginalizing, seemingly, the music itself and leaving little room for musicological or historical approaches. ${ }^{4}$ That has spawned consequent anxiety that the two schools may never have a common platform of communication. I would suggest through the present example that this is not necessarily so - or at any rate, that such isolation is not determined forever by some fatal limitation of the Hungarian approach.

As Kodály and Bartók enhanced their theoretical work after World War I, in comprehensive studies of what constitutes Hungarian folk music, ${ }^{5}$ they soon

2. Olga Szalay, Kodály, a népzenekutató és tudományos mühelye [Kodály the folk music researcher and his scholarly workshop] (Budapest: Akadémiai Kiadó, 2004); Kodály Zoltán és tanítványai [Kodály and his pupils], ed. Melinda Berlász (Budapest: Rózsavölgyi, 2007).

3. Timothy Rice, Ethnomusicology. A Very Short Introduction (Oxford: Oxford University Press, 2014), 1.

4. For a comparison of the two schools, see Péter Laki, "Bartók és a nemzetközi etnomuzikológia" [Bartók and international ethnomusicology], Holmi 18/8 (August 2006), 1070-1073.

5. Béla Bartók, A magyar népdal [Hungarian folk song] (Budapest: Rózsavölgyi, 1924); first English edition: Hungarian Folk Music, transl. M. D. Calvocoressi (Oxford: Oxford University Press, 1931). Kodály's study first appeared as a chapter in a broader work of ethnography: Zoltán Kodály, "Zene" [Music], A magyarság néprajza [Ethnography of the Hungarians], ed. Elemér Czakó (Budapest: Királyi Magyar Egyetemi Nyomda, 1937), vol. IV, 9-79. It appeared the same year as a separate volume: Zoltán Kodály, A magyar népzene [Hungarian folk music] (Budapest: Királyi Magyar Egyetemi Nyomda, 1937); first English edition: Folk Music of Hungary, transl. Ronald Tempest and Cynthia Jolly, rev. Laurence Picken (London: Barrie and Rockliff, 1960). Note that the titles of both English-language books are imprecise translations. 
raised new questions of why and how - questions of the life of the music, as they often put it. Bartók, in his study "Why and How Do We Collect Folk Music?" (1935) warns that "collection of melodies as if they were isolated items ... is not an adequate approach." Much rather should "the folk music collector investigate in detail the conditions surrounding the real life of the melodies." "Similarly Kodály, in the foreword to the first separate edition of his Magyar népzene (1937), suggests as topics for further research "the life and physiology of the tune", "music in the life of the community", "the folk's instruments and their ways with instruments", and "the musical life of peasant bands and of village Gypsies ignorant of notation." He also states as a monographic principle: "It would be most informative to prepare a complete map of tunes of a particular village, along with a description of its musical life to the utmost detail, that is to say, its musical monograph."7 For this new train of thought, Bartók and Kodály no doubt took valuable inspiration from the Romanian school established by the sociologist Dimitrie Gusti and the ethnomusicologist Constantin Brăiloiu. ${ }^{8}$ The influence came just in time, for it agreed with the Hungarians' logic of turning to sociology having settled the basic musical questions.

The seminars on ethnomusicology that Kodály started at the University of Budapest in 1930 brought a new generation of students into folk music research. A leading figure was László Lajtha (1892-1963), then head of the Department of Folk Music at the National Museum. The backbone of their work consisted in a gramophone-recording and publishing project known as Patria, initiated in $1936 .{ }^{9}$ The recordings mainly made at the Hungarian Radio also involved a growing number of field trips and phonograph recordings. The gramophone, opening an era of high-quality recordings of folk music, even in multiple parts, inspired Lajtha's thoughts on a complex reality beyond the musical surface. As he writes in a report on the Patria project in 1938:

Folk music is no lifeless object. Folk music is endowed with a soul - a living organism. It is alive as long as it is capable of new transformations, and its life consists in this eternal change. ... Nor is it merely the tune we hear. The tune is but one ephemeral manifestation of the living process we call folk music. ${ }^{10}$

6. Béla Bartók, "Why and How Do We Collect Folk Music," in idem, Essays, ed. Benjamin Suchoff (London: Faber, 1976), 19-20.

7. The foreword is omitted from the English editions; I quote Kodály, A magyar népzene, 6-7 in my own translation.

8. Bartók, "Why and How Do We Collect Folk Music," 20-22. Cf. Gábor Lükő, "A román "monografisták’ falukutató munkája" [Village research by the Romanian "monographers"], Honismeret könyve, ed. Antal Bodor (Budapest: A Magyar Társaság Falukutató Intézete, 1935), 117-124.

9. Patria. Magyar népzenei gramofonfelvételek / Hungarian Folk Music Recordings 1936-1963, ed. Ferenc Sebő [with DVD-ROM supplement] (Budapest: Hungarian Heritage House, 2010).

10. Lajtha László összegyüjtött írásai [Collected writings of László Lajtha], vol. I, ed. Melinda Berlász (Budapest: Akadémiai Kiadó, 1992), 96. My translation. 
When he later published his monographs of folk music collected in the early 1940s, he coined new terms for his approach, such as "biology of folk music."11

Historical events that gave further impetus to research in those years were the so-called Vienna Awards, whereby Hungary regained some territories ceded after World War I, including Northern Transylvania with the Székely Land from Romania and the Hungarian-speaking south of Czechoslovakia. These were peripheral parts of the Hungarian language area, and as such, favored fields of research for Kodály and Bartók back in the years of the Dual Monarchy, offering a treasure trove for ethnomusicologists. Some young researchers took the chance to follow Kodály's advice and write a monograph on the musical life of a specific village. Lajos Vargyas researched the village of Áj (in Slovak: Háj), Upper Hungary, ${ }^{12}$ and Pál Járdányi did a similar study of Kide (in Romanian: Chidea), Northern Transylvania. ${ }^{13}$

Oszkár Dincsér, born in 1911, studied in Budapest from 1935 at the Academy of Music and University Faculty of Arts, attending Kodály's classes at both. Concurrently he assisted Lajtha at the Ethnographic Collection of the National Museum, being involved in the Patria project, including several field trips. He often took the photographs and trained himself into a remarkable ethnographic photographer (for some photographs made by him, see Plate l $a-c$ ) - perhaps that is why no photograph of him has been found. ${ }^{14} \mathrm{He}$ traveled to the East Transylvanian county of Csík in January and July 1942 and published his results a year later. ${ }^{15}$

Csík was established in the medieval Kingdom of Hungary as an autonomous administrative unit (szék) of the Székely Land and retained this privileged status until 1871. Under the administrative reform of 1876 it became instead a simple county (vármegye). It has several sub-regions of different ethnographic characters, such as Csík Basin (i.e. Csík in the narrow sense), Gyergyó Basin in the North, and Gyimes Valley in the Eastern Carpathians, with its distinct Hungarian ethnic group known as the Gyimes Csángó. From 1907 onward, the county played a key role in Kodály and Bartók's discovery of the Hungarian musical idiom, for

11. László Lajtha, Szépkenyerüszentmártoni gyüjtés [Collection in Szépkenyerüszentmárton (in Romanian: Sânmartin)] (Budapest: Zeneműkiadó, 1954), 3.

12. Lajos Vargyas, Ájfalu zenei élete [Musical life of the village of Áj] (Budapest: A Kir. Magy. Pázmány Péter Tudományegyetem Magyarságtudományi Intézete, 1941). New edition with complete collected music: Egy felvidéki falu zenei világa $=$ The Musical World of a Hungarian Village - Áj, 1940, ed. János Bereczky (Budapest: Planétás, 2000).

13. Pál Járdányi, A kidei magyarság világi zenéje [Secular music of the Hungarians from Kide] (Kolozsvár: Minerva, 1943).

14. For a summary of extant documents of Dincsér's activity, see Melinda Berlász, "Dincsér Oszkár kutatásai a 'Pátria'-felvételek összefüggésében. Egy évtized a Néprajzi Múzeum népzenei műhelyében (19351944)" [Dincsér's research connected with the "Patria" recordings. A decade in the folk music workshop at the Museum of Ethnography], Zenetudományi Dolgozatok 2001-2002 [Studies in musicology 2001-2002], ed. Márta Sz. Farkas (Budapest: MTA Zenetudományi Intézet, 2002), 121-144.

15. Oszkár Dincsér, Két csíki hangszer. Mozsika és gardon [Two instruments from Csík. Fiddle and gardon] (=A Néprajzi Múzeum füzetei 7) (Budapest: Magyar Történeti Múzeum, 1943). Printed in 500 copies, it is now a rarity worth republishing. 
Plate 1a Gypsy fiddler Lajos Duduj and his wife, playing at a barn dance.

Csíkszentdomokos (Sândominic), July 1942

Budapest, Museum of Ethnography, Photograph Collection, F 154212

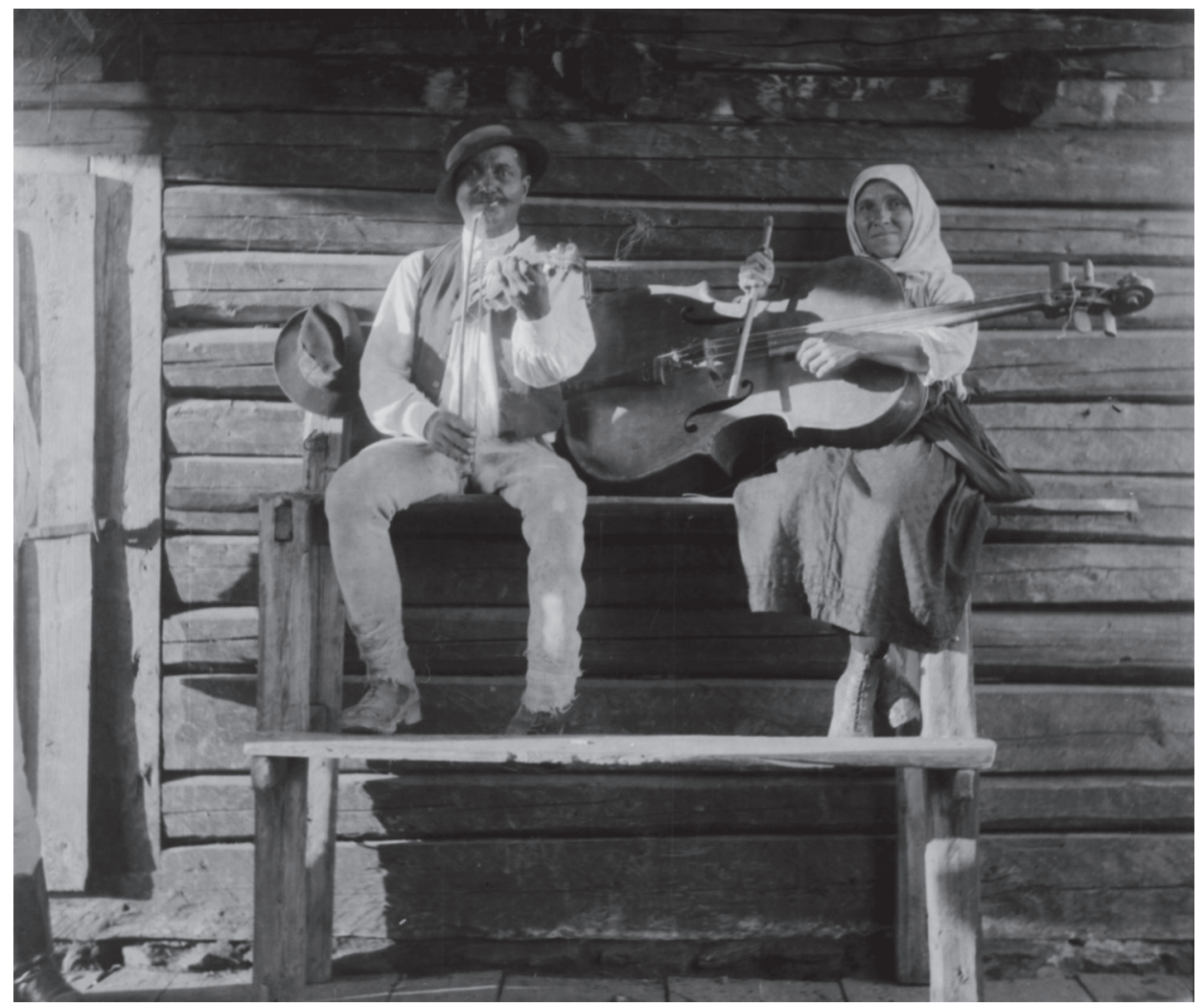

it revealed the importance of the pentatonic scale, provided the bulk of their first scholarly publication of folk songs, ${ }^{16}$ and inspired many of their compositions. Fieldwork in Csík was continued in the early 1910s by Antal Molnár and László Lajtha. While most of the material collected consisted of songs, Kodály's and Molnár's collections included tunes played on the fiddle (mozsika), with little reference to accompaniment or other issues of instrumental practice. ${ }^{17}$

Yet, Dincsér's main concern was precisely instrumental practice. He was the first to present the traditional fiddle/gardon duo as Csík's basic form of dance music. The gardon is a stringed percussion instrument with two or three thick gut strings that are beaten with a stick in the right hand, and a thinner string that is

16. Béla Bartók and Zoltán Kodály, Erdélyi magyarság. Népdalok [Hungarians from Transylvania. Folksongs] (Budapest: Népies Irodalmi Társaság - Rózsavölgyi és Társa, [1923]).

17. Lujza Tari, Kodály Zoltán, a hangszeres népzene kutatója [Zoltán Kodály, the researcher of instrumental folk music] (Budapest: Balassi, 2001). 
Plate 1b Csángó fiddler György Gábor (b. 1911) and his wife.

Kostelek (Coşnea), July 1942

Budapest, Museum of Ethnography, Photograph Collection, F 154216

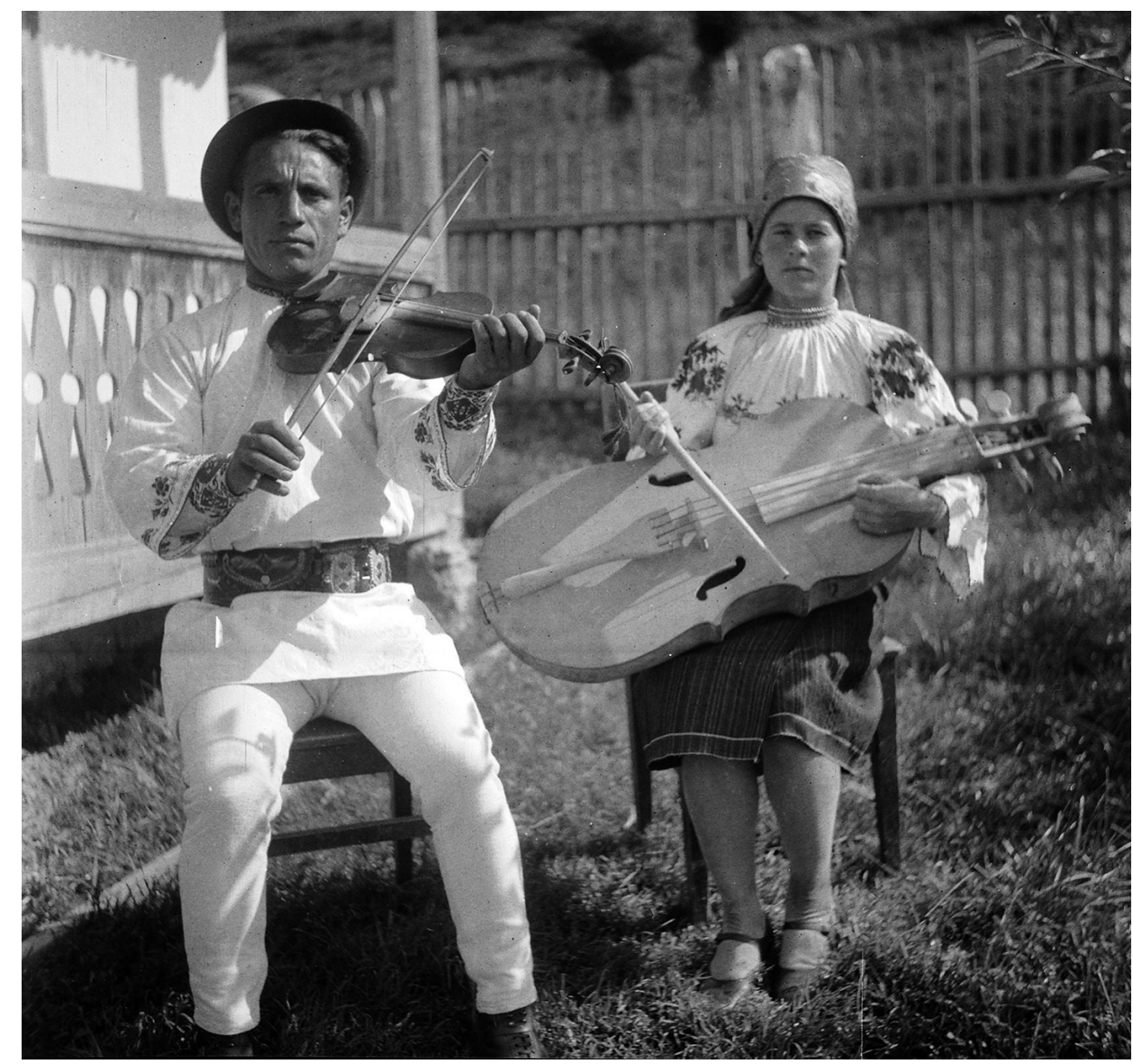

plucked with the left, so that it hits the fingerboard. This duo type was retained mainly in Gyimes, while sometimes it was augmented in the Csík Basin by a second fiddle (kontra) for rhythmic and harmonic accompaniment, or in Gyergyó by a cimbalom.

The author clearly follows all the new guidelines of his tutors to provide a complete description of musical life centered on the instruments themselves ( Table 1).

His main methods are interviews and observations. He illustrates the text with a wealth of photographs and sketches. Captions and a three-page abstract are provided also in German. 
Plate 1c Hungarian flute player. Csíkszentmihály (Mihăileni), July 1942

Budapest, Museum of Ethnography, Photograph Collection, F 154228

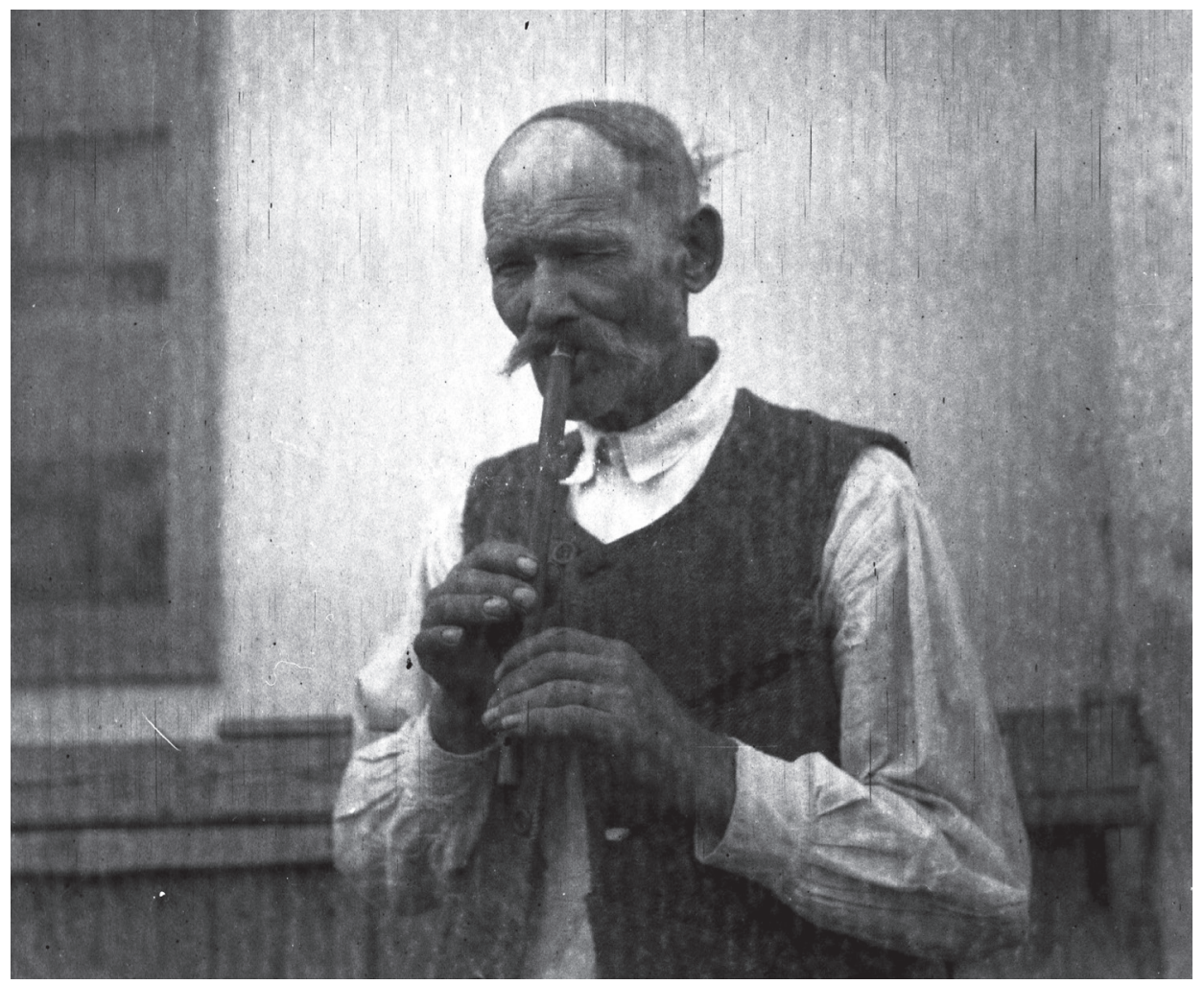

TABle 1 Chapters in Oszkár Dincsér, Két csíki hangszer. Mozsika és gardon [(Two instruments from Csík. Fiddle and gardon)]

\begin{tabular}{|l|l|l|}
\hline A falusi hangszeres zene & $(3-8)$ & Village instrumental music \\
\hline A csíki zenészek & $(6-8)$ & The musicians of Csík County \\
\hline A mozsika & $(8-47)$ & The fiddle [including sections on] \\
\hline A zenélés tanulása & $(8-17)$ & \multicolumn{1}{|c|}{ Learning the music } \\
\hline A hangszer müszavai, készitése, javitása & $(17-31)$ & $\begin{array}{l}\text { The instrument's terminology, } \\
\text { making, and reparations }\end{array}$ \\
\hline A hangszer meghangolása, gondozása & $(31-32)$ & $\begin{array}{l}\text { The tuning and maintenance of } \\
\text { the instrument }\end{array}$ \\
\hline A játéktechnika & $(32-47)$ & The technique of playing \\
\hline A gardon & $(47-58)$ & The gardon [with similar sections] \\
\hline A zenészek a társadalomban & $(58-70)$ & The musicians in local society \\
\hline A két hangszer történeti kérdései & $(71-84)$ & $\begin{array}{l}\text { Historical problems of the two } \\
\text { instruments }\end{array}$ \\
\hline Zwei Musikinstrumente aus dem Komitate Csík & $(85-87)$ & [Abstract in German] \\
\hline
\end{tabular}


During his fieldwork, Dincsér also made sound recordings filling 47 phonograph cylinders ${ }^{18}$ with 133 items: about two hours of music amounting to the largest monographic collection of Hungarian instrumental music at that time. However, he never transcribed his recordings, and the study addresses no issues of musical analysis at all. Though an adept transcriber, he must have deliberately refrained from devoting time to transcription, giving precedence to publishing the real novelty of his research as soon as possible. He obviously felt the threat of military service increase every day.

Thus he seems to have reversed the priorities of early Hungarian research, providing almost no information on the tunes, but as much as possible on the musical culture. This already suggests that Dincsér's approach resembled that of the American school. To test this, I compared his study with a classic of American ethnomusicology, Alan P. Merriam's The Anthropology of Music. ${ }^{19}$

Merriam's aim was to define a canon for what had been taking shape at several American universities as a new discipline, devoting a chapter to each suggested approach and reviewing the literature deemed relevant. ${ }^{20}$ His chapters are entitled "Concepts," "Synesthesia and intersense modalities," "Physical and verbal behavior," "Social behavior: the musician," "Learning music," "The process of composition," "The study of song texts," "Uses and functions of music," "Music as symbolic behavior," "Aesthetics and the interrelationship of the arts," "Music and culture history," and "Music and cultural dynamics."

Merriam pleads for a certain equilibrium between the anthropological and musicological approaches, but follows the German school of comparative musicology in understanding the latter as the study of music in its physical, rather than intellectual, reality ("the structure of music sound as a system in itself"). ${ }^{21}$ So the list bears no trace of musical analysis, yet overlaps early Hungarian research on two points: "The study of song texts," and "Music and culture history."

The next section examines the presence of these topics in Dincsér's book. This does not presuppose a correspondence of explicit theoretical ideas, as most of Dincsér's work is clearly practice-centered. Much rather the question is to what extent his interest overlaps Merriam's topics or how far he perceives phenomena that will play key roles in the future school of musical anthropology. My assumption is that everything he wrote about counted to him as relevant data, even if he was led by intuition rather than theoretical consciousness.

18. Wax cylinders MH 4140-4187 of the Museum of Ethnography, Budapest.

19. Alan P. Merriam, The Anthropology of Music (Evanston, Illinois: Northwestern University Press, 1964). When referring to a chapter as a whole, I omit page references.

20. The book has indeed had a great impact, but of course it cannot tell everything of the early American school. A list of further milestones might include David P. McAllester, Enemy Way Music (Cambridge, Massachusetts: Peabody Museum, 1954); Bruno Nettl, Theory and Method in Ethnomusicology (Glencoe, Illinois: The Free Press of Glencoe, 1964); Mantle Hood, The Ethnomusicologist (New York: McGraw-Hill, 1971); Charles Seeger, Studies in Musicology 1935-1975 (Berkeley, California: University of California Press, 1977).

21. Merriam, Anthropology, 3-5. Italics added by me. 


\section{Concepts}

Merriam's first chapter deals with issues to do with what a community thinks of its own music: what it accepts as music and what not, the meaning of musical talent, the importance of music to the community, and the origins of music.

Dincsér's introductory chapter gives his first sketch of a conceptual framework for a new discipline, research into Hungarian instrumental folk music, and summarizes his field experience: "In folk ${ }^{22}$ life, instrumental music and dance music usually coincide. ... Singing is not considered, or called, music." ${ }^{23}$ Later he attests to an interest in views on musical talent and motivation, as he quotes an informant: "as a child I was already mad about it." ${ }^{24} \mathrm{He}$ observes that "even in peasant environments, aptitude and talent play major roles in acquiring fiddle technique. By contrast, the gardon, an instrument calling for much simpler technique, requires no special musical talent; anyone with a decent sense of rhythm can handle it;"25 "playing the gardon is no difficult trade."26

One piece of negative information shows Dincsér's interest in folk beliefs associated with music: "In the course of my fieldwork I found no superstitious beliefs whatsoever in connection with the fiddle or the gardon."27

\section{Synesthesia and intersense modalities}

This topic inspired by psychology and German comparative musicology ${ }^{28}$ leaves no trace in Dincsér's study or Hungarian ethnomusicology as a whole. Merriam's example ${ }^{29}$ suggest it could be productive in studying art music or extra-European musical cultures, rather than the Hungarian tradition.

\section{Physical and verbal behavior}

In this chapter Merriam includes the techniques of playing an instrument or singing, bodily postures in music-making, physical and psychic responses to music, verbal statements and judgements about music, as well as cueing and signaling while playing.

22. For the concept of "folk" in Hungarian ethnomusicology, see László Dobszay and Janka Szendrei, Catalogue of Hungarian Folksong Types: Arranged According to Styles, vol. I. (Budapest: Institute for Musicology of the Hungarian Academy of Sciences, 1992), 8.

23. Dincsér, Két csíki hangszer, 3. Quotations are given in my own translation.

24. Ibid., 11. I keep Dincsér's italics which refer to excerpts of his field interviews.

25. Ibid., 83 .

26. Ibid., 49.

27. Ibid., 70.

28. Merriam, Anthropology, 85.

29. Ibid., 91-101. 
Dincsér devotes fifteen pages to local fiddle technique and three to gardon technique, supporting his statements with interview excerpts and illustrating them with photos and drawings. As a violinist, he shows great sensitivity to deviations from classical technique and sound ideal, or from his earlier experience, noticing even personal traits. His descriptions are probably the richest and most accurate achievable without film records.

He also gives examples of judgments in music: "He could never learn to play in tune." ${ }^{30}$ Merriam notes a general tendency to denigrate younger generations in traditional musical cultures ${ }^{31}$ - something Dincsér, too, observes: "Elderly Csángó take a low view of youngsters' songs and dancing." 32

One modest remark concerns signaling while playing music: "the kettös [dance] is the hardest [to accompany]. My husband, playing it, gives me a sharp look if I do it wrong." 33

\title{
4. Social behavior: the musician
}

Questions of musicians' social status and their social and cultural relations to those calling on them have featured in broad Hungarian discourse since the nineteenth century. ${ }^{34}$ Dincsér's introductory chapter presents the traditional "Gypsy question," discussed earlier by Kodály, Bartók, and Lajtha, in a new, micro-social context that summarizes his own experience:

\begin{abstract}
An instrumentalist ... is separated from the community by his very profession, although he keeps in contact with it. ... The more reliant he is on his profession as an instrumentalist, the more exposed he is to the community. Still, in one way he is above the intellectual level of the community. ... The musician may transcend the average level of musicality in his community, but his social status is below average, which makes his position peculiar in village society. ... Music-making has gradually become a specific job of the Gypsies. ${ }^{35}$
\end{abstract}

Thereafter the author lists and evaluates his informants under the title "The Csík musicians," and elaborates on their social relationships in a twelve-page chapter:

30. Dincsér, Két csíki hangszer, 8.

31. Merriam, Anthropology, 162.

32. Dincsér, Két csíki hangszer, 68.

33. Ibid., 58.

34. At the latest since the much-debated book by Franz Liszt, Des Bohémiens et de leur musique en Hongrie (Paris : Bourdilliat, 1859); first Hungarian edition: A czigányokról és a czigány zenéröl Magyarországon, transl. József Székely (Pest: Heckenast, 1861).

35. Dincsér, Két csíki hangszer, 3-4. 
"The musicians in society." He is interested in the bearing of ethnic and social status on music-making, and relations of Gypsy musicians and peasant musicians:

Most musicians placed themselves as Gypsies, although anthropologically, they frequently belonged to clearly non-Gypsy types.36 Peasant musicians are found only among the Csángó of Gyimes, but the best of them have positively learned from Gypsies. ${ }^{37}$

In [the village of] Lok [Lunca de Jos], the best musicians are Gypsies; here ... the Csángó play better. ${ }^{38}$

None of the Gypsies here speak the Gypsy language and few of them speak any Romanian. ${ }^{39}$

The author observes that the musician's role - to use the terms adopted by Merriam $^{40}$ - is an "ascribed" one in the case of Gypsies: "every child must learn the craft according to his birth, so a musician's child must learn to play" 41 whereas for Hungarian peasant musicians, it is an "achieved" one: "My father couldn't stand me playing, he even forbade me to play. He had his rules: he was a true farmer and he didn't want any Gypsy ways in the family."

Dincsér pays attention to the social relationship between fiddler and accompanist:

The gardon player is usually the fiddler's wife. 43

An unmarried fiddler would take anyone who agrees to play the gardon, usually men or boys, occasionally little girls. The reason for this is of a social nature, for a woman would never go and make music with any man save her husband, and adolescent girls prefer to dance at a party. 44

The book contains abundant examples of the interaction between musicians and customers, such as payment: "They would put the money into the gardon or fiddle

36. Note the use of the term "anthropology" in a physical, not a cultural sense.

37. Dincsér, Két csíki hangszer, 8-9.

38. Ibid., 9.

39. Ibid., 67.

40. Merriam, Anthropology, 131, quoting Ralph Linton, The Study of Man (New York: D. Appleton-Century, 1936), 115.

41. Dincsér, Két csíki hangszer, 16.

42. Ibid., 10.

43. Ibid., 48 .

44. Ibid., 49. 
[through the sound holes], or into the hair of the bow, ${ }^{455}$ but on the other hand, they would firmly demand service even from an exhausted musician: "Hey, I've just stood up [to dance], keep playing!" ${ }^{\prime 6}$ Especially valuable is a transcription of a will left by a Csángó woman, ordering particular musicians to play at her own burial. ${ }^{47}$ Bargaining, one of the most important phases of the interaction, is also described:

When the musician names the charge he demands, the organizer of the party will usually find it too high. ... Bargaining will sometimes go on for an hour or two before they reach an agreement. ${ }^{48}$

\section{Learning music}

The learning of music is another of Dincsér's important topics, discussed in an eight-page section. He interviews each informant on the matter and groups the answers thematically.

Merriam distinguishes three forms of learning music: socialization, education, and schooling. ${ }^{49}$ Dincsér's interviews outline two trends in this respect. With peasant musicians, aural and visual musical socialization plays a decisive role, as they usually can seldom count on any form of tuition: "I had many years of trouble and toil; I kept trying to do what I'd heard from the Gypsies." ${ }^{50}$ On the other hand, children of Gypsy musician families usually get tuition from several relatives, albeit for short periods, followed by a phase of socialization while they play together with their tutors. ${ }^{51}$ With education, Dincsér sees two further tendencies. In some cases, pupils are first taught rhythmic and harmonic accompaniment on the fiddle (kontrázás), even if local tradition does not use the instrument for that purpose. In Other Cases, education means teaching tunes from the very beginning..$^{52}$

Like Merriam, ${ }^{53}$ Dincsér also sees practicing as of interest, yet all he finds is negative evidence:

Peasant musicians do not practice. ... They gain their routine not at home, but at dancing parties, where they play one tune after the other, for hours on end. ${ }^{54}$

45. Ibid., 63.

46. Ibid., 41.

47. Ibid., 66.

48. Ibid., 58-59.

49. Merriam, Anthropology, 146.

50. Dincsér, Két csíki hangszer, 10.

51. Ibid., 11.

52. Ibid., 15-17.

53. Merriam, Anthropology, 159-161.

54. Dincsér, Két csíki hangszer, 38. 


\section{The process of composition}

Here Merriam investigates, from an emic point of view, cases of individual creation, by which he means primarily "how new songs are brought into being." ${ }^{55}$ This approach seems appropriate for oral cultures lacking a dichotomy of art music and folk music, rather than in a European context. Yet what many of Merriam's examples show is not conscious composition, but a metaphysical or visionary invention of songs thought of as new - another strain inspired by psychology. ${ }^{56}$

There is no trace of this field in Dincsér's work. He seems to accept the basic tenet of the Hungarian school that no tunes are composed as folk music - they become folk music, where an appropriate community accepts them as its own. ${ }^{57}$ As Lajtha puts it, "Folklore is never an individual creation, always a communal creation. The main feature of folklore specimens is not that their composer is unknown, but that they cannot have a composer." 58

In this train of thought, processes of composition lie outside the field of folk music, and have no bearing on folk music culture. Of far more interest would be the composition of musical sequels out of tunes and variations, a field of research that Merriam disregards. Dincsér, however, risks some rudimentary observations in this respect, of a kind that can be made without lengthy sound recordings. ${ }^{59}$

\section{The study of song texts}

In Hungary and many other European countries, interest in folk music was preceded and inspired by a cult of "folk poetry" in the late eighteenth and early nineteenth centuries. Here, too, Dincsér departs from tradition. He neglects song texts precisely by concentrating on instrumental practice and musicians, who as he observes, "usually do not know the song texts." 60

However, Dincsér's body of recordings testifies to his interest in the relations between instrumental and vocal material. He recorded several melodies in both an instrumental and a vocal variant ${ }^{61}$ and some purely vocal ones, ${ }^{62}$ sung by musicians or their wives in most cases. But as he did not transcribe the recordings and probably took no notes while recording, he does not even mention these texts in his study. He merely quotes a few incipit lines of songs not included among

55. Merriam, Anthropology, 165.

56. Ibid., 264.

57. Dobszay and Szendrei, Catalogue, 8, 12.

58. Berlász, ed., Lajtha írásai, 97.

59. Dincsér, Két csíki hangszer, 70.

60. Ibid., 69.

61. MH 4143a-4143b, 4150-4153b, 4174a-4174c, 4174b-4174d, 4186a-4186b.

62. MH 4144a, 4150, 4151, 4152a, 4152c, 4176a, 4176b, 4177a, 4177b. 
them. ${ }^{63}$ In classifying instrumental genres, he starts by distinguishing tunes that can be sung to a text and those that cannot, ${ }^{64}$ but he lacked important insights to dance culture to pursue the classification further.

\section{Uses and functions of music}

Merriam distinguishes between "uses" and "functions" of music. By uses he understands superficial, practical, conscious aims such as dance, courtship, or prayer. Functions, on the other hand, are more general, unconscious aims such as aesthetic pleasure, communication, or social cohesion.

As Dincsér writes a descriptive, practice-oriented work, he deals at length with uses, but ventures no hypotheses on functions. He discusses the uses in a major, coherent section, detailing the events accompanied by music, such as weddings, christenings, barn dances, or funerals.

Yet Dincsér, like Merriam, remains silent on the single most important use of instrumental music (at least in Csík): accompanying dance. To conceptualize on dance form and relate it to musical form would of course need a background of scholarly folk dance research, which had gone no further than its very first steps by that time in Hungary.65 Moreover, he probably failed to set up occasions to observe the region's traditional dances.

\section{Music as symbolic behavior}

This chapter of Merriam's discusses cases where music has some extra-musical, symbolic meaning for the community.

Dincsér had intuition about the major symbolic meaning of traditional music: the representation of individual and common identities, as distinguished from those of others.66 Examples are found in relations between Székely67 and Csángó people, Hungarians and Gypsies, as well as Hungarians and Romanians, respectively.

63. Dincsér, Két csíki hangszer, 61.

64. Ibid., 68-69.

65. László Lajtha and Sándor Gönyey, “Tánc” [Dance], A magyarság néprajza, vol. IV, 80-153. Other research into Hungarian folk dance done in the early 1940s was published after the war: István Molnár, Magyar tánchagyományok [Hungarian dance traditions] (Budapest: Magyar Élet, 1947).

66. Cf. István Pávai, Az erdélyi magyar népi tánczene [Folk dance music of the Hungarians in Transylvania] (Budapest: Hagyományok Háza, Kriza János Néprajzi Társaság, 2013), 116-120.

67. Hungarian inhabitants of the Székely Land have a strong sense of identity based on their historic privileges, which they maintain in opposition to Romanians as well as other Hungarians, such as the Csángó of Gyimes. 
It is not only the Csángó who differentiate in [regional and social strata of] songs, but also the Székely of Csík. I asked some about tunes I had collected in Gyimes, and as a rule they answered straight off: this is Csángó stuff! - which means they do not admit such archaic tunes as their own. ${ }^{68}$

Even [among the Csángó], some plaintive songs have sunk down to the Gypsies and live on with a new function as Gypsy songs. ${ }^{69}$

What Romanians play is mongrel music: half is of the Hungarian kind, but they have distorted the Hungarian tunes. ${ }^{70}$

Some tunes and equivalent dances may have very powerful symbolic meanings, indeed several self-contradictory meanings. A case in point is the chain dance known as héjsza or szírba (a loan from the Romanian name sârbă). In Gyimes, both denote the same dance and the same set of tunes. The latter name spread more recently; its use had higher social prestige, while it could be seen to endow the dance with a clear Romanian character. In the short period of reinstated Hungarian administration, Dincsér observed that the recently applied name szirba had compromised the dance with Hungarians inside and outside the community, causing them to neglect or prohibit it. ${ }^{71}$

Another special case put forward is the genre of "the shepherd seeking his flock", as a form of program music with an entertainment function. Distinct parts of the musical sequence denote lamentation, horn signals, and joy, in that order. ${ }^{72}$

\section{Aesthetics and the interrelationship of the arts}

The title of the chapter refers initially to an inquiry into the relations of the communities studied to aesthetic concepts found in the Western culture of art music. Merriam's examples suggest these relations are mostly contradictory: they provide negative aesthetics, as it were, for ethnic music. The basic reason for this is that traditional cultures do not conceive of music as a separate object, which can be analyzed in aesthetic terms, but rather as a means to an end, inseparable from a specific context. Lajtha likewise demands: "Let us not act as aesthetes in the case of folklore; no oral culture has concepts of the beautiful or the ugly." 73

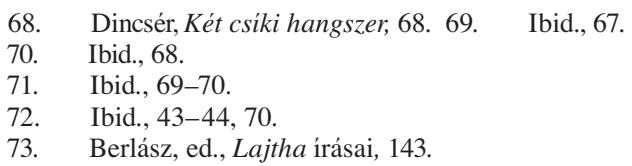


Dincsér's informants seem aware of two kinds of music and two aesthetic standards. They concede that the needs of their community, in terms of tunes, performing style, or range of instruments, differ from those of higher social strata.

He just plays Csángó tunes in a Csángó way; he may know some songs of gentlefolk, but those he learned from other musicians: musicians of a better kind. ${ }^{74}$

We don't do it here the way they do in town ... where fiddlers just make tiny bow movements; here you have to play with force..$^{75}$

When we play for gentlefolk, we need a kontrás [accompanying fiddler]; but the Csángó want nothing but the tune; each fiddler plays by himself, with a $\operatorname{gardon} .^{76}$

Alongside such consciously felt differences, Dincsér observes unconscious practice, finding in it still greater deviation from art-music aesthetics: "A Gyimes kontrás would provide an accompaniment of a mainly rhythmical nature, feeling no need to fit the tune harmonically." 77

The author's subjective aesthetic judgments, to which he gives vent here and there, have special value for the history of scholarship:

Melodies played with added parallel fifths sound a little strange at first, but later give an increasingly intensive, sensual, fresh impression. ${ }^{78}$

Csángó fiddlers play these tunes with a simple freshness ... while the play of those in Upper Csík have an air of the well-known, and the fiddler of Gergyóújfalu shows a vitality - whether intended or sincerely experienced - of conscious performance. ${ }^{79}$

The second phrase in Merriam's chapter title, "the interrelationship of the arts," would most obviously mean, in the case of Csík, the relations of music and dance, but it has been shown that his work is not strongly dance conscious. So Dincsér does not get far in identifying the musical genres, failing to see how most of them derive from dance genres. ${ }^{80}$

74. Dincsér, Két csíki hangszer, 40-41.

75. Ibid., 41.

76. Ibid., 16.

77. Ibid., 43.

78. Ibid., 45.

79. Ibid., 47.

80. Cf. ibid., 69. 


\section{Music and culture history}

Merriam notes that this topic had been seen as outmoded by the young American school, until they recognized how the history of many African peoples, attested by very few written sources, cannot be reconstructed without recourse to folk tradition. ${ }^{81}$ Such consciousness has been central to Hungarian folklore research since its very beginnings.

Lack of transcribed material prevented Dincsér from investigating the cultural history of tunes or texts. His diachronic interest appears in instrument history; his views on that appear in the 14 pages of his last chapter. It is here that he most inclines to hypothesize, with arguments clearly influenced by evolutionist trends in the German school of comparative musicology (notably Curt Sachs). First he seeks historical analogies of the fiddle that includes a sympathetic string, as used in Gyimes, and of the violin technique and learning methods he found. ${ }^{82}$ To this he adds only an unreferenced remark on the history of tunes: "Some dance tunes of Transylvania without a text retain an intellectual relation of some kind to certain layers of old West European dance music." 83 On the other hand, he notes that the gardon owes its form to the viols of sixteenth-century Western Europe, though it changed its function at some time, adopting that of the drum used earlier, slipping back to a "primitive" existence that contrasts with the morphological development it had undergone as a bowed instrument. ${ }^{84}$

\section{Music and cultural dynamics}

Merriam's last chapter looks at changes in culture which may occur within the frame of a particular culture, i.e. by innovation, or by a process of cross-cultural influence or acculturation. Acculturation usually leads to cultural syncretism, a melding of elements from different cultures. Another possible outcome he calls compartmentalization: elements of different cultures not melding, but continuing in use separately in the same community.

Dincsér finds syncretic phenomena in relation to the influence of Hungarian urban culture ${ }^{85}$ and of Romanian culture. ${ }^{86}$ Compartmentalization, on the other hand, or musical bilingualism, is a natural part of a village fiddler's trade. ${ }^{87}$

81. Merriam, Anthropology, 277.

82. Dincsér, Két csíki hangszer, 71-75.

83. Ibid., 83 .

84. Ibid., 75-84.

85. Ibid., 12, 38.

86. Ibid., 9, 13, 67.

87. Ibid., 16. 
Dincsér understands that regional and sub-regional cultural differences derive mainly from differences in processes of cultural dynamics, to do with repertoires, instrument sets, and the morphology of instruments. "Comparing recent research and earlier collections in Csík County reveals that the repertoire of archaic tunes has greatly fallen among the Csík Székely, while still found among the Csángó." 88 On changes in sets of instruments he notes: "The kontrás was added to the band as a third member under the influence of gentlefolks' music." ${ }^{89}$ On changes in instrument morphology he opines: "Gardons of the new type - ribbed gardons - are not peasant handiwork, but bought ready-made as cellos. ... Cellos so transformed are then used the same way as an old-style gardon." 90

An important role in cultural dynamics is played by new generations under new external influences. Although Merriam takes no notice of the issue, Dincsér does:

Partying folks (the lads) want other tunes; they do not like these Csángó kind of tunes. ... People of old knew nothing of the waltz, they had the old German dance instead, and they danced it beautifully, too. Nowadays it is all messed up, and they cannot dance to that properly either. ${ }^{91}$

This also explains Dincsér's unpleasant memories of the one occasion he attended a barn dance:

At Szentdomokos [Sândominic], it almost came to blows at one young people's dance. The soldiers on leave kept demanding a waltz, so I had to listen to tunes in triple meter ${ }^{92}$ for two hours on end, at what was supposed to be a Székely dance in Upper Csík. ${ }^{93}$

Comparing the two works shows that six of Merriam's twelve topics are treated at length in Dincsér's book: behavior in connection to music, the social role of musicians, learning music, uses of music, music and culture history, and music and cultural dynamics. He touches on four other topics with less emphasis or scarcer data: concepts, aesthetics, song texts, and music as symbolic behavior. That leaves only two he does not treat at all: composition and synesthesia, both of doubtful relevance to his field of research. Also similar are the weaknesses of the two in showing little sensitivity to the morphology of music or dance. 
To sum up, Dincsér discusses or at least considers nearly every approach of the future American school of musical anthropology; he surely deserves to be seen as a forerunner. Yet this is remarkable not only as an individual achievement: his approach clearly draws on the guidance of his tutors Kodály and Lajtha, shared by most colleagues of his generation. A comparison with Merriam's work would give similar results for the contemporaneous monographs of Vargyas and Járdányi ${ }^{94}$ Thus Kodály's school of ethnomusicology seems to arrive in the early 1940s through organic development (inevitably as it were) at the same methods and principles that would constitute the American school a decade later.

However, the anthropological tradition was marginalized after World War II in favor of the large Corpus project. ${ }^{95}$ Only partial amends were made by the rise of a Hungarian school of folk-dance research in the 1950s, headed by György Martin. An additional loss is that Dincsér's career ended the very next year after his volume was published. In 1944, as the German army occupied Hungary, he was drafted into labor service and taken to the Reich, where he subsequently spent several months as a prisoner of war. He eventually decided not to return, but to settle in Switzerland. There he published his only paper in a foreign language, a German version of his study on problems of variants in folk music research ${ }^{96}$ However, he soon lost contact with academic life as well as his native land.

The prospects in Dincsér's legacy include doing the work he never had a chance to do: transcribe his recordings and analyze the musical material, which I undertook for an MA thesis at the Liszt Academy of Music. I feel this may complete his research as a balanced work of anthropological and of musicological value.

94. Vargyas, Áj; Járdányi, Kide.

95. A Magyar Népzene Tára - Corpus Musicae Popularis Hungaricae, vols. I-XII. (Budapest: Akadémiai Kiadó, 1951-2011).

96. Oscar Dincsér, "Die Probleme der Varianten in der Volksmusikforschung. Mit besonderer Hinweise auf die ungarische Folklore," Cahiers de Frontenex (Genève) 1947, 59-86. Reviewed in Journal of the International Folk Music Council, 1 (1949), 64-65. In Hungarian: Dincsér, Oszkár, "A változat a magyar népzenei kutatásban," Emlékkönyv Kodály Zoltán hatvanadik születésnapjára = Mélanges offerts à Zoltán Kodály à l'occasion de son soixantième anniversaire, ed. Béla Gunda (Budapest: Magyar Néprajzi Társaság, 1943), $128-138$. 
